DOI: $10.33067 /$ SE.2.2020.1

Sylwia K. Mazur $\star$

\title{
Doubtful Ally or Ally Full of Doubts? The Course of Transatlantic Relations under Donald Trump's Presidency
}

\begin{abstract}
Donald Trump's "America-first" diplomacy has undermined the foundations of many alliances, including a transatlantic relationship on which post-war liberal order would rest. Under the current American presidency, EU-US relations are facing significant challenges whose implications are still far from clear. The list of discrepancies between the allies are growing ever longer and the American administration's decisions are antithetical to those taken by Brussels and other European capitals. Divisions, among other things, have occurred over policies towards the Paris Climate Agreement, Joint Comprehensive Plan of Action and the Middle East approach. The special relationship between Europe and United States can no longer be taken for granted. In this presented paper, the author has looked beyond current political disagreements in order to focus on the long term factors underlying the "special relationship". The rationale behind this research is the dawn of great power politics that happens during the transition from uni-to-multipolar order. America's disengagement from (and defunding of) the global scene means that the European Union will have to adjust to a world with numerous centres of power and different sources of threat. Ursula von der Leyen announced, upon assuming office in December 2019, that she would lead a "geopolitical Commission" engaged in tackling global challenges. All of this in the face of the first American administration in post-war history that opposes European integration.

Due to the space limit (and deservedness for sole attention), the security and defence dimension of transatlantic cooperation will only be briefly mentioned. Regardless of any comments made by former European
\end{abstract}

^ Sylwia K. Mazur - University of Information Technology and Management in Rzeszów, e-mail: smazur@wsiz.rzeszow.pl, ORCID: 0000-0002-9596-0797. 
Commission President Jean-Claude Juncker that the European Union will not create an alternative model to $\mathrm{NATO}^{1}$, the creation of a Permanent Structure Cooperation (PESCO) and the establishing of a European Defence Fund cannot be omitted. Enhanced European defence will be essential for a "healthy transatlantic partnership with the United States"2. That partnership will, almost certainly, become more transactional.

Keywords: Transatlantic Relations, European Union, United States, Donald Trump, Multilateralism

\section{Not-so-special Relationship}

When Harry S. Truman in 1947 asked Congress for assistance for Greece and Turkey, ${ }^{3}$ both endangered by the communism, it was not only a de facto declaration of the Cold War, but also a signal that after Second World War Washington will not return to isolationism. From that moment the United States would provide assistance to any democratic nation under threat from authoritarian forces. American president argued that security of the US territory depended on it. During Cold War United States built the alliance system that would allow them to secure the international balance of power. Soviet Union's containment was focused primarily in Europe. The transatlantic alliance has become the bedrock of post-war order based on liberal democratic values and principles. Cooperation resulted in the creation of the United Nations, the World Bank, the International Monetary Fund, the General Agreement on Tariffs and Trade (which set foundations for World Trade Organization), NATO and eventually the European Union.

Unification of Europe has been embedded within a strong transatlantic dimension. Partners on both sides of the Atlantic Ocean shared values, interests and concerns. EU-US was the most powerful, comprehensive and important relationship in the world. ${ }^{4}$ But that relationship was never easy and almost from the beginning of the Cold War oscillated between highs and lows. Among lows were Suez crisis in 1956 and final years of the Vietnam War. When the Cold War was over American security

1 European Commission, Towards a European Defence Union, Towards a more united, stronger, more democratic Union, May 2019.

2 Shared Vision, Common Action: A Stronger Europe. A Global Strategy for the European Union's Foreign And Security Policy, June 2016.

${ }^{3}$ H.S. Truman, Address Before a Joint Session of Congress, Washington D.C., 12.03. 1947.

4 G. Burghardt, The European Union's Transatlantic Relationship, "EU Diplomacy Papers", no. 2/2006, p. 3. 
engagement in Europe has decreased. During short "unipolar moment" some cleavages between transatlantic partners became uncovered.

In 2001, George W. Bush withdrew the United States from Kyoto Protocol which seek to reduce emission of greenhouse gases. ${ }^{5}$ In a letter sent to group of senators, president stated his opposition to Kyoto Protocol explaining that act exempted " 80 per cent of the world, including major population centers such as China and India, from compliance and would cause serious harm to U.S. economy". ${ }^{6}$ His view was supported by Senate which had voted not to ratify the treaty. Two weeks earlier President announced that his administration will not try to regulate power plants' emission of carbon dioxide. ${ }^{7}$ European Union decided to the take lead in international climate-change control. In a letter sent to the White House and signed by the President of European Commission Romano Prodi and Swedish Prime Minister Goran Persson, EU has stressed that global strategy to tackle climate change is integral part of the EU-US relations. ${ }^{8}$ It have not change Washington's position.

But the new low in Transatlantic relations were about to happen when France and Germany refused to join "coalition of the willing" in the Iraq war. Discussions surrounding invasion of Iraq provoked also intraEuropean crisis. ${ }^{9}$ American Defense Secretary Donald Rumsfeld called France and Germany "problem" and "old Europe", contrasting them with the "vitality" of Central Easter European countries. ${ }^{10}$ The rift was especially visible from NATO perspective. Eight member states aligned themselves with Washington. Lack of support by European powers was in contrast to Gulf War I when George H.W. Bush secured help from thirty-four countries, many of whom provided substantial military support. ${ }^{11}$ In the end, George W. Bush's foreign policy has shattered the American moral and political authority, even among long-standing allies such as Canada and France. ${ }^{12}$

5 In the end, only three countries with targets under the Protocol have not ratified it: Australia, Monaco and the United States.

${ }^{6}$ G.W. Bush, Letter from the President to Senators Hagel, Helms, Craig, and Roberts, March 13, 2001.

7 D. Jehl, A.C. Revkin, Bush, in Reversal, Won't Seek Cut In Emissions of Carbon Dioxide, "The New York Times", March 14, 2001, Section A, Page 1.

${ }^{8}$ Reuters News Service, Bush Reversal Outrages Europeans EU says climate strategy "integral" to U.S. relations, 23.03.2001.

9 French President threat to block accession of Central European countries to the European Union.

${ }_{10}$ M. Baker, U.S.: Rumsfeld's 'Old'And 'New'Europe Touches On Uneasy Divide, Radio Free Europe, 24.01.2003, https://www.rferl.org/a/1102012.html (access 17.04.2020).

${ }_{11}$ The list of supporters included also Arab countries.

12 F. Zakaria, The Self-Destruction of American Power, "Foreign Affairs", no. 98(4), July/August 2019, p. 13. 
With the rise of People's Republic of China the focus on Asia had to grow. The "Pivot to Asia" was one of major Barack Obama's administration foreign policy initiatives. According to one member of the administration, U.S. was "not pivoting away" from long-time allies, but "rebalancing its diplomatic, economic and strategic focus". ${ }^{13}$ The centerpiece of that shift was Trans-Pacific Partnership which could give American economy possibility to expand its reach in overseas markets. ${ }^{14}$ The agreement aimed to deepen economic ties, slashing tariffs and fostering trade to boost growth between eleven countries in the Pacific rim and United States. ${ }^{15}$ In geopolitical dimension, it would have enhance American influence and could serve as a tool reassuring friends and foes that the United States is "multi-dimensional power fully anchored to the region". ${ }^{16}$ But first and foremost, it would serve as counterweight to China's dominance in the region. ${ }^{17}$ That rebalance was a clear signal that after a decade long presence in Afghanistan and Iraq United States are ending Bush-era focus on Middle East and fight with terrorism. Barack Obama tried to shape new global order, where United States was in the lead but responsibilities and burdens were shared whenever possible or necessary. ${ }^{18}$

\section{Donald Trump's Presidency. Between Ignorance and Blunt Rebuffs}

From the beginning of his campaign Donald Trump seemed to ignore fact that one of the reasons behind Pax Americana was the alliance system. His slogan "America First" sent strong signal that under Donald Trump's lead United States will abdicate global stewardship responsibilities. ${ }^{19}$ In the past relationship with Western Europe and later with European Union

13 J. Davidson, The U.S. "Pivot to Asia”, “American Journal of Chinese Studies", vol. 21, June 2014, p. 78.

14 According to projections, the trade deal would bring extra annual income gains ranging between 57 billion and 131 billion USD by 2032 .

15 Except United States, it included Australia, Brunei, Canada, Chile, Japan, Malaysia, Mexico, New Zealand, Peru, Singapore and Vietnam.

16 M. Solis, The Trans-Pacific Partnership. The politics of openness and leadership in the Asia-Pacific, Brookings Institute, Asia Working Group, Paper 6, October 2016, p. 1.

17 B. Obama, The TPP would let America, not China, lead the way on global trade, "The New York Times", 2.05.2006, https://www.washingtonpost.com/opinions/president-obamathe-tpp-would-let-america-not-china-lead-the-way-on-global-trade/2016/05/02/680540e40fd0-11e6-93ae-50921721165d_story.html (access 22.04.2020).

18 M.S. Indyk, K.G. Lieberthal, M.E. O’Hanom, Scoring Obama's Foreign Policy, "Foreign Affairs", no. 19(3), pp. 30-31.

19 X. Wickett, Transatlantic Relations Converging or Diverging?, Chatham House Report, January 2018, p. 3. 
was a pillar of that stewardship. What surprised many, including European leaders, was President Trump's negative opinion of the EU, which can also be perceived as opposition to European integration. ${ }^{20}$ As a presidential candidate Donald Trump hailed the results of the Brexit referendum, claiming it was a "great victory" 21 and as a president, he encouraged the United Kingdom to walk away from negotiation table, if they cannot secure a favourable Brexit deal. ${ }^{22}$ President's political instincts are clearly Jacksonian- based on populist nationalism and only sporadically concerned with foreign policy. It is in contrast to Barack Obama's vision of "renewing American leadership" in a "multipolar world". ${ }^{23}$

Apart from policy differences - described below - Trump's presidency has also brought unprecedented sense of ideological drift between partners. President's antagonism toward multilateralism is contrary to European approach. Current President of European Commission Ursula von der Leyen in her agenda for Europe clearly stated that "multilateralism is in Europe's DNA", ${ }^{24}$ which is a clear acknowledgement that multilateral system is in vital interest of EU member states.Lack of habit of bargaining in the global system can be crucial obstacle in new reality with reemerging Russia and domineering China. ${ }^{25}$ The list of EU's vulnerabilities is longer and includes fragmentation of decision-making process, which is in the stark contrast of centralized Russia and China. Internal obstacles include cohort of backsliders among which some were courted by Vladimir Putin.

Old partners cannot even agree on a vital issue like Middle East conflict. American recognition of Jerusalem as Israel's capital in 2017 raised objections among Europeans. During informal breakfast with Israeli Prime Minister Benjamin Netanyahu, then High Representative

20 In May 1950 President Harry Truman offered American support for the European Coal and Steel Community which initiated path toward EU-US decades-long cooperation. See: H. Truman, Official Statement, 18.05.1950, https://www.cvce.eu/content/ publication/1997/10/13/b1645976-b15d-4d58-9303-d40424987f56/publishable_en.pdf (access 22.04.2020).

${ }^{21}$ E. MacAskill, Donald Trump arrives in UK and hails Brexit vote as 'great victory', "The Guardian", 24.01.2016, https://www.theguardian.com/us-news/2016/jun/24/donaldtrump-hails-eu-referendum-result-as-he-arrives-in-uk (access 23.04.2020).

${ }_{22}$ T. Higgins, Trump encourages no-deal Brexit ahead of state visit, offers Britain trade deal with US, CNBC, 2.06.2019, https://www.cnbc.com/2019/06/02/trump-tells-ukto-walk-away-if-eu-doesnt-agree-to-brexit-deal.html (access 23.04.2020).

${ }^{23}$ B. Obama, Renewing American Leadership, "Foreign Affairs", July/August 2007.

${ }^{24} \mathrm{U}$. von der Leyen, A Union that strives for more. My agenda for Europe, Political Guidelines for the Next European Commission 2019-2024.

${ }_{25}$ M. Leonard, J. Saphiro, Empowering EU Member States with Strategic Sovereignty, European Council on Foreign Relations, June 2019, p. 3. 
of the Union for Foreign Affairs and Security Policy Federica Mogherini and twenty-eight ministers of foreign affairs clearly stated that European Union will not join United States in its recognition and that the solution to Middle East conflict can be only based on two states, with Jerusalem as the capital of both, Israel and Palestine. ${ }^{26}$ American credibility as a neutral party in Middle East conflict was significantly undercut. In January 2020, President Trump's administration unveiled Mideast peace proposal. ${ }^{27}$ Plan could be easily described as "diplomatic malpractice" due to its pro-Israeli bias. ${ }^{28}$ Palestinians were promised a potential "state", but only under particular conditions. ${ }^{29}$ Josep Borrell's statement forcefully denounced American proposal, accusing US of departing from commitment to a negotiated two-State solution. ${ }^{30}$

In May 2018 President Trump announced that the United States would withdraw from Joint Comprehensive Plan of Action (JCPOA). Despite the decision, seven of the original eight parties, including European Union, adhered to the agreement. ${ }^{31}$ Following President Trump's announcement, EU emphasized its commitment to the implementation of the JCOP and ensured that positive effects of sanctions-lifting should continue. ${ }^{32}$ Relations with Iran become more "complex"when American President authorized decision to kill Iran's top military commander Qassem Soleimani. Teheran retaliated by firing missiles at bases in Iraq used by U.S. soldiers and announcement that it would further reduce its compliance with JCOP. United Kingdom, France and Germany replied with triggering a formal dispute-resolution. Nations rejected Iran's argument that violation of the deal was justified by United States' decision. On a European Union level High Representative of the Union for Foreign

26 European External Action Service, Netanyahu realised there is full EU unity on Jerusalem, Mogherini says after EU Foreign Affairs Council, 12.12.2017.

27 White House, Peace to Prosperity. A vision to improve the lives of the Palestinian and Israeli People, Washington D.C., January 2020.

${ }^{28}$ Apart from its content, Plan was released in presence of Israeli Prime Minister Benjamin Netanyahu, Palestinian leaders were absent.

29 Vast majority of Israeli settlements on Palestinian territory would be recognized as a part of Israeli State. Palestinians would receive mostly desert territory. Jerusalem as Israel's capital would be "undivided". Palestinian capital could be located to the east and north of the city. Jordan valley would be recognized as Israeli territory.

${ }^{30}$ European Union External Action Service, MEPP: Statement by the High Representative/Vice-President Josep Borrell on the US initiative, Brussels, 4.02.2020.

31 Original Parties of the Agreement (in alphabetical order): China, European Union, France, Germany, Iran, Russia, United Kingdom and United States.

32 European Union External Action Service, Declaration by the High Representative on behalf of the EU following US President Trump's announcement on the Iran nuclear deal (JCPOA), Brussels, 10.05.2018. 
Affairs and Security Policy is doing everything to prove that EU is able to pursue foreign policy independently from United States. During his first visit to Iran, in February 2020, Josep Borrell underlined European Union's willingness to deepen its bilateral cooperation. ${ }^{33}$

In November 2019 United States has begun to formally leave Paris climate agreement, ${ }^{34}$ although decision was announced by President two years earlier when he cited "draconian financial and economic burdens" the agreement imposes on Washington. ${ }^{35}$ It means that state that has contributed to global warming will not be a part of international charge to solve it. ${ }^{36}$ Donald Trump's decision is just one of the attempts to remove environmental guardrails installed by previous administrations ${ }^{37}$ and is in stark contrast to EU's actions. Ursula von der Leyen's made "European Green Deal" one of six headline ambitions for her Commission, vowing to make Europe "the world's first climateneutral continent". ${ }^{38}$ Some EU policymakers used Donald Trump's move to call for steeper emissions cuts. ${ }^{39}$ Not only that, but Brussels joined forces with Canada and China to co-convene annual ministerial summits on climate action. ${ }^{40}$

Managing global pandemia of COVID-19 has also been riddled with disagreements. In mid-March 2020 Donald Trump announced travel ban from most EU member states. Decision was not consulted with European counterparts. At the beginning of May 2020, European Union organized pledge to collect 7.5 billion euro for COVID-19 diagnostics, treatments and vaccine. Two great absentees? United States and Russia.

33 European Union External Action, Press release following High Representative/ Vice-President Josep Borrell's official visit to Iran, Brussels, 4.02.2020.

${ }_{34}$ M.R. Pompeo, On the U.S. Withdrawal from Paris Agreement (Press Statement), 4.11.2019.

35 D. Trump, Statement by President on the Paris Climate Accord, Washington, 1.06.2017.

36 Paris Agreement allowed parties to set their own nationally determined contributions and lacked enforcement mechanism. Both solutions were introduced to accommodate US position and allow President Barack Obama to sign it as an executive agreement which does not require Congressional approval.

37 President Trump took number of actions to weaken climate policies, among others: to relax restrictions on power plant emission, to stop payments to the Green Climate Fund, to appoint lawyer who opposed environmental regulations, as a head of Environmental Protection Agency.

${ }^{38}$ U. von der Leyen, op. cit.

39 The Greens/EFA in the European Parliament, US formally requests to withdraw from Paris Climate Agreement, Press Release, Brussels, 5.11.2019.

${ }^{40}$ Third Ministerial on Climate Action (MoCA) took place in June 2019 and was held in Brussels. 
The list of disagreements becomes longer and almost every American decision in foreign policy astounds not only commentators of public life, but also allies. In December 2019, president Trump unilaterally withdraw American forces from Syria. U.S. disengagement from Syria created power vacuum which allowed Russia to seal its presence in the region. The US President has also lifted restrictions on the use of anti-personnel landmine by American forces which were introduced by Barack Obama's administration. EU condemned that decision saying that their use, regardless of place, time and entity using it, is unacceptable to the European Union. ${ }^{41}$

\section{Can Trade Save This Relationship?}

Despite of the tensions, European and American combined economies account for one third of world trade and nearly $50 \%$ of global gross domestic product. The US is EU's main export destination, absorbing nearly one fifth of total European Union goods exports. United States are second, lagging behind China, among EU's import partners. Trade relations for a long time were heralded as the cornerstone of the transatlantic relationship. Nonetheless, it did not prevent President Trump from complaining that European Union's position on trade is "worse than China" and that EU treats the US "horribly". ${ }^{42} \mathrm{He}$ called the EU "foe", although he noted "that doesn't mean they are bad... it means that they are competitive". ${ }^{43}$ Tensions between the European Union and United States has escalated in 2018. US imposed tariffs of $10 \%$ on aluminum and $25 \%$ on steel imported from Europe. The basis for that were alleged national security concerns. European Union has retaliated. After World Economic Forum which took place in January, 2020 Trump has announced that negotiations on new trade deal with European Union will be hold before November election. Even if it can be seen as positive momentum for trade talks, the chances that negotiations will be politicized for campaign purposes are high, especially that President Trump's comments reflect his core belief, that the United States are exploited by its partners.

${ }^{41}$ European External Action Service, Anti-personnel mines: Statement by the Spokesperson on the United States' decision to re-introduce their use, Statement by the Spokesperson, Brussels, 4.02.2020.

42 The Irish Times, Trump: 'The European Union is worse than China', 16.08.2019, https://www.irishtimes.com/news/world/us/trump-the-european-union-is-worse-than-china-1.3988164 (access 22.04.2020).

${ }^{43}$ Face the Nation, "I think the European Union is a foe," Trump says ahead of Putin meeting in Helsinki, 15.07.2018, https://www.cbsnews.com/news/donald-trump-interview-cbs-news-european-union-is-a-foe-ahead-of-putin-meeting-in-helsinki-jeff-glor/ (access 25.04.2020). 
Another bone of contention is a digital tax. Washington angrily responded to France's new tax imposed on large technology companies which include American Amazon, Apple, Google and Facebook, threatening to retaliate with high tariffs on exports, including luxury goods and wine. ${ }^{44}$ Although French government has explained that drive behind it is to make companies with global revenues above 750 million euro to pay "fairer" taxes, Washington believes it is unfairly aimed at American business. European Commission reacted quickly by ensuring that EU will "act and react as one, and will remain united". ${ }^{45}$

Donald Trump exploited public fear over Transatlantic Trade and Investment Partnership (TTIP). Agreement was another "victim" of Trump's aversion to trade deals. On his first day in office, President abandon the Trans-Pacific Partnership. It is quite paradoxical that president igniting trade war with China pulls the country out from deal which could strengthenUnited States' leverage in the region and give Beijing more incentives for changing its behavior ${ }^{46}$ The North American Free Trade Agreement (NAFTA), which was called by the president "the worst trade deal ever made", was renegotiated. As an outcome, the United States Mexico Canada Agreement (USMCA) was signed. There are also background tensions regarding American blockage of new appointments to the Appellate Body in the World Trade Organization, effecting in paralysis of the second appeals step of the dispute settlement system. It was United States than in the past strongly advocate for creation of appellate body. Access to it was considered crucial for ensuring that countries could challenge decisions by ad hoc panels and for consistency when disputing over legal texts. ${ }^{47}$

\section{"Global Europe" with "Strategic Autonomy"?}

The increasingly global nature of threats like environmental pollution, security of energy supply, pandemics or networks of terrorism demand

44 Trump Donald J., Twitter, (@realDonaldTrump), 26.07.2019, https://twitter.com/ realDonaldTrump/status/1154791664625606657?ref_src=twsrc\%5Etfw\%7Ctwcamp $\% 5 \mathrm{E}$ tweetembed\%7Ctwterm\%5E1154791664625606657\&ref_url=https\%3A\%2F\%2Fwww. theguardian.com $\% 2$ Fworld $\% 2 \mathrm{~F} 2019 \% 2 \mathrm{Faug} \% 2 \mathrm{~F} 23 \% 2 \mathrm{Ff}$ rench-wine-makers-hope-forg7-detente-with-trump-over-tariffs (access 24.04.2020).

45 J. Valero, We will 'react as one', EU tells US over French digital tax dispute, "The Euractiv", 3.12.2019, https://www.euractiv.com/section/digital/news/we-will-react-asone-eu-tells-us-over-french-digital-tax-dispute/ (access 22.04.2020).

46 E. Alden, Trump and the TPP: Giving Away Something for Nothing, Council on Foreign Relations, 23.01.2017.

47 J.A. Hillman, A Reset of the World Trade Organization's Appellate Body, Council on Foreign Relations, 14.01.2020. 
states and international organizations to work together. While global problems cannot be solved European Union or United States alone, their robust cooperation can create stewardship and bring other states to address regional and global problems. Weak cooperation will leave vacuum and allow other parties to fill the void. But with Donald Trump at helm, Europeans are starting to realize that American democracy is no longer producing consensual politics with predictable foreign policy and that the change of president, can also mean a new regime. ${ }^{48}$

In February 2019, during Munich Security Conference, Joe Biden assured politicians and security experts that Americans "will be back", adding that "American people understand that it's only by working in cooperation with our friends that we are going to be able to harness the forces of a rapidly changing world, to mitigate their downsides and turn them to our collective advantage". ${ }^{49}$ But assumption that Democratic candidate will win November elections bear too much risk. Especially, that damage done to transatlantic relations by Trump's presidency might be irreparable.

The decay of transatlantic relations has not started with Donald Trump, nor it will end with his presidency. One of the reasons behind the rifts can be the power asymmetry between United States and Europe, which for a long time has been not only accepted, but also cultivated. As Alina Polyakowa and Benjamin Haddad put it "Europe remained submissive in exchange for a spot underneath the U.S. defense umbrella". ${ }^{50}$ What is crucial is the fact that membership in the European Union and NATO overlaps. Currently twenty one states belong to both organizations. Tensions between transatlantic partners have arisen not only over EU plans to strength its capabilities, but also on strategies to solve dispute in the Western Balkans.One of the main challenges imposed by Trump's administration is mismatch between president's actions and that of the foreign policy professionals in current administration. At 2020 Munich Security Conference, Michael Pompeo said, "the death of the transatlantic alliance is grossly over-exaggerated". ${ }^{51}$ It was the same State Secretary that in December 2018 delivered speech on "Restoring the Role of the Nation

48 I. Krastev, Will Europe Ever Trust America Again?, "The New York Times", 3.12.2019.

49 ProductiehuisEU, \#MSC2019: Joe Biden tells Europeans that America is 'an embarrassment' (Munich Security Conference), 16.02.2019, https://www.youtube.com/ watch? $\mathrm{v}=\mathrm{Ab} 470 \mathrm{~h} 3 \mathrm{X} 8 \mathrm{I} 8$ (access 22.04.2020).

50 A. Polyakova, B. Haddad, Europe Alone. What Comes After the Transatlantic Alliance, "Foreign Affairs", no. 98(4), July/August 2019, pp. 109-110.

${ }_{51}$ M.R. Pompeo, The West Is Winning, Speech, Munich, 15.02.2020. 
State in the Liberal International Order" in which he named failings of international institutions. Not only the list included European Union, but also a call to Europeans urging them to "reassert their sovereignty", which clearly echoed Donald Trump's sentiments. ${ }^{52}$

Cracks in transatlantic relations (and Brexit) brought member states to work closer on security and defense. An urgent need for "strategic autonomy" is reflected in "Strategy for Foreign and Security Policy" published in June 2016. In her foreword, Federica Mogherini underlined that priorities like common interest of European citizens, principles and values are "best served in an international rules and on multilateralism". ${ }^{53}$ Also, Ursula von der Leyen underlined in political guidelines for European Commission that more needs to be done toward "genuine" European Defence Union. ${ }^{54}$

Voices calling for "strategic autonomy" can be also heard from national capitals. In his Sorbonne speech delivered in September 2017, Emanuel Macron stated that in the area of defence, Europe needs to gain "autonomous operating capabilities". ${ }^{55}$ In 2016 European leaders have agreed on plan to deepen security and defence. European Defence Fund have been launched. Apart from contributing to Europe's strategic autonomy, the Fund coordinates member states investments in defence technology and catalyze for an innovative technology and equipment solutions. Twenty five member states have jointly developed Permanent Structured Cooperation - permanent framework for closer cooperation and a process for deepening defence cooperation within EU framework. The measure can evolve under pressure from "serious and acute hybrid threats" which are a part of a reality. ${ }^{56}$

\section{Conclusions}

Times have changed. The world is constantly shifting, from bipolarity during Cold War through unipolar moment (aka Pax Americana or "end of history" moment) to times which can be described as "polynodal”, ${ }^{57}$

${ }_{52}$ M.R. Pompeo, Remarks by Secretary Pompeo on Restoring the Role of the Nation-State in the Liberal International Order, Speech, Brussels, 4.12.2018.

${ }^{53}$ Shared Vision, op. cit.

${ }^{54}$ U. von der Leyen, op.cit.

55 E. Macron, Sorbonne speech, Paris, 26.09.2017.

${ }^{56}$ U. von der Leyen, op. cit.

57 European Strategy and Policy Analysis System, Global Trends to 2030. Challenges and Choices for Europe, April 2019. 
post-bipolar order or "multipolar disorder". ${ }^{58}$ To put it simply "the jungle grows back" ${ }^{59}$ According to Richard Gowan from International Crisis Group, Europe has to become a practical champion of multilateralism. Especially that in regard to global governance, Americans have had tendency to be more skeptical about multilateral institutions and mechanisms that Europeans. For EU current situation might be an opportunity to become a third pole in geopolitics (along with China and the U.S.). ${ }^{60}$ But for this to happen, European Unionhas to create political, economic and military capacity to address growing challenges from different parts of the world. As Josep Borrell said, Europe needs to learn "to use the language of power". ${ }^{61}$ In other words, Europe must "develop appetite for power". ${ }^{62} \mathrm{New}$ era of great power competition has arrived.

\section{References}

Alden E., Trump and the TPP: Giving Away Something for Nothing, Council on Foreign Relations, 23.01.2017.

Baker M., U.S.: Rumsfeld's 'Old' And 'New' Europe Touches On Uneasy Divide, Radio Free Europe, 24.01.2003, https://www.rferl.org/a/1102012. $\mathrm{html}$ (access 17.04.2020).

Borrell J., Opening statement, Hearing of Josep Borrell Fontelles, High

Representative/Vice President-designate of the European Commission, Brussels, 7.10.2019.

Burghardt G., The European Union's Transatlantic Relationship, "EU Diplomacy Papers”, no. 2/2006.

Bush G.W., Letter from the President to Senators Hagel, Helms, Craig, and Roberts, March 13, 2001.

Davidson J., The U.S. "Pivot to Asia", "American Journal of Chinese Studies", vol. 21, June 2014.

EU must develop 'appetite for power' says foreign policy chief fosepBorrell,

17.02.2020, https://www.youtube.com/watch?v=1iBPySIGx-o (access 25.04.2020).

58 B. Rios, Borrell: COVID-19 outbreak 'has ended up blowing up' the global order, Euractive, 7.05.2020, https://www.euractiv.com/section/global-europe/news/borrellcovid-19-outbreak-has-ended-blowing-up-the-global-order/ (access 20.05.2020).

59 See: R. Kagan, The jungle grows back, Knopf 2018.

${ }^{60}$ R. Gowan, A. Dworkin, Three Crises and an opportunity: Europe's stake in multilateralism, Policy Brief, European Council on Foreign Relations, September 2019.

${ }^{61}$ J. Borrell, Opening statement, Hearing of Josep Borrell Fontelles, High Representative/Vice President-designate of the European Commission, Brussels, 7.10.2019.

${ }^{62}$ Euronews, EU must develop 'appetite for power'says foreign policy chief Josep Bor$\mathrm{rell}, 17.02 .2020$, https://www.youtube.com/watch?v=1iBPySIGx-o (access 25.04.2020). 
European Commission, Towards a European Defence Union, Towards a more united, stronger, more democratic Union, May 2019.

European External Action Service, Anti-personnel mines: Statement by the Spokesperson on the United States' decision to re-introduce their use, Statement by the Spokesperson, Brussels, 4.02.2020.

European Strategy and Policy Analysis System, Global Trends to 2030. Challenges and Choices for Europe, April 2019.

European Union External Action Service, Declaration by the High Representative on behalf of the EU following US President Trump's announcement on the Iran nuclear deal (JCPOA), Brussels, 10.05.2018.

European Union External Action Service, MEPP: Statement by the High Representative/Vice-President Josep Borrell on the US initiative, Brussels, 4.02.2020.

European Union External Action Service, Netanyahu realised there is full EU unity on Jerusalem, Mogherini says after EU Foreign Affairs Council, 12.12.2017.

European Union External Action, Press release following High Representative/ Vice-President Fosep Borrell's official visit to Iran, Brussels, 4.02.2020.

Face the Nation, "I think the European Union is a foe," Trump says ahead of Putin meeting in Helsinki, 15.07.2018, https://www.cbsnews.com/news/ donald-trump-interview-cbs-news-european-union-is-a-foe-ahead-ofputin-meeting-in-helsinki-jeff-glor/ (access 25.04.2020).

Gowan R., Dworkin A., Three Crises and an opportunity: Europe's stake in multilateralism, Policy Brief, European Council on Foreign Relations, September 2019.

Hillman J.A., A Reset of the World Trade Organization's Appellate Body, Council on Foreign Relations, 14.01.2020.

Indyk M.S., Lieberthal K.G., O'Hanom M.E., Scoring Obama's Foreign Policy, "Foreign Affairs", no. 19(3).

Jehl D., Revkin A.C., Bush, in Reversal, Won't Seek Cut In Emissions of Carbon Dioxide, "The New York Times", March 14, 2001, Section A, Page 1.

Kagan R., The jungle grows back, Knopf 2018.

Krastev I., Will Europe Ever Trust America Again?, “The New York Times”, 3.12.2019.

Leonard M., Saphiro J., Empowering EU Member States with Strategic Sovereignty, European Council on Foreign Relations, June 2019.

von der Leyen U., $A$ Union that strives for more. My agenda for Europe,

Political Guidelines for the Next European Commission 2019-2024.

Macron E., Sorbonne speech, Paris, 26.09.2017. 
Obama B., The TPP would let America, not China, lead the way on global trade, "The New York Times", 2.05.2006, https://www.washingtonpost. com/opinions/president-obama-the-tpp-would-let-america-not-chinalead-the-way-on-global-trade/2016/05/02/680540e4-0fd0-11e6-93ae50921721165d_story.html (access 22.04.2020).

MacAskill E., Donald Trump arrives in UK and hails Brexit vote as 'great victory', "The Guardian", 24.01.2016, https://www.theguardian.com/ us-news/2016/jun/24/donald-trump-hails-eu-referendum-result-as-hearrives-in-uk (access 23.04.2020).

Polyakova A., Haddad B., Europe Alone. What Comes After the Transatlantic Alliance, "Forreign Affairs", no. 98(4), July/August 2019.

Pompeo M.R., On the U.S. Withdrawal from Paris Agreement (Press Statement), 4.11.2019.

Pompeo M.R., Remarks by Secretary Pompeo on Restoring the Role of the Nation-State in the Liberal International Order, Speech, Brussels, 4.12.2018.

Pompeo M.R., The West Is Winning, Speech, Munich, 15.02.2020.

ProductiehuisEU, \#MSC2019: Foe Biden tells Europeans that America is 'an embarrassment' (Munich Security Conference), 16.02.2019, https://www. youtube.com/watch?v $=\mathrm{Ab} 470 \mathrm{~h} 3 \mathrm{X} 8 \mathrm{I} 8$ (access 22.04.2020).

Reuters News Service, Bush Reversal Outrages Europeans EU says climate strategy "integral" to U.S. relations, March 23, 2001.

Rios B., Borrell: COVID-19 outbreak 'has ended up blowing up' the global order, Euractive, 7.05.2020, https://www.euractiv.com/section/globaleurope/news/borrell-covid-19-outbreak-has-ended-blowing-up-theglobal-order/ (access 20.05.2020).

Shared Vision, Common Action: A Stronger Europe. A Global Strategy for the European Union's Foreign And Security Policy, June 2016.

Solis M., The Trans-Pacific Partnership. The politics of openness and leadership in the Asia-Pacific, Brookings Institute, Asia Working Group, Paper 6, October 2016.

The Greens/EFA in the European Parliament, US formallyrequeststowithdraw from Paris Climate Agreement, Press Release, Brussels, 5.11.2019.

The Irish Times, Trump: 'The European Union is worse than China', 16.08.2019, https://www.irishtimes.com/news/world/us/trump-theeuropean-union-is-worse-than-china-1.3988164 (access 20.04.2020).

Truman H.S., Address Before a Foint Session of Congress, Washington D.C., 12.03.1947.

Truman H.S., Official Statement, Washington D.C., 18.05.1950.

Trump D.J., Twitter, (@realDonaldTrump), 26.07.2019, https://twitter. com/realDonaldTrump/status/1154791664625606657?ref_src $=$ twsrc $\%$ 
5Etfw\%7Ctwcamp\%5Etweetembed\%7Ctwterm\%5E115479166462560 $6657 \&$ ref_url=https\%3A\%2F\%2Fwww.theguardian.com $\% 2$ Fworld\% 2F $2019 \% \overline{2}$ Faug\% 2 F23\%2Ffrench-wine-makers-hope-for-g7-detentewith-trump-over-tariffs (access 24.04.2020).

Trump J.D., Statement by President on the Paris Climate Accord, Washington D.C., 1.06.2017.

Valero J., We will 'react as one', EU tells US over French digital tax dispute, "The Euractiv", 3.12.2019, https://www.euractiv.com/section/digital/ news/we-will-react-as-one-eu-tells-us-over-french-digital-tax-dispute/ (access 22.04.2020).

White House, Peace to Prosperity. A vision to improve the lives of the Palestinian and Israeli People, Washington D.C., January 2020.

Wickett X., Transatlantic Relations Converging or Diverging?, Chatham House Report, January 2018.

Zakaria F., The Self-Destruction of American Power, "Forreign Affairs", no. 98(4), July/August 2019. 